\title{
The effect of inflation on the optimum payback cut-off
}

\author{
J.U. de Villiers \\ Department of Business Economics, University of the Witwatersrand, P.O. Wits, Johannesburg 2000, Republic of South Africa
}

Received 29 August 1990; accepted 14 November 1990

\begin{abstract}
Despite the theoretical criticisms against it, payback is one of the most commonly used methods of investment appraisal in practice. Its ease of calculation and simplicity are seen as its most important advantages. In addition, an unsophisticated method like payback can yield the correct investment decision as long as the correct cut-off is specified. In this paper the optimum payback cut-off and how it is influenced by inflation is studied. Threc different methods of calculating payback under inflation are investigated. In all of these the optimum cut-off depends upon the type of assets (current, depreciable or non-depreciable assets) as well as the life of depreciable assets employed. The study shows that the optimum nominal payback cut-off (where the payback calculation is based on inflated cash flows) decreases with increasing inflation for all asset types. The optimum real payback cut-off (based on nominal cash flows adjusted for inflation) does not change with inflation. The optimum uninflated payback cut-off (where inflation is ignored) decreases rapidly with inflation for projects employing current assets. In the paper is shown that complex but systematic relationships exist between a project's payback period and its discount rate. Despite its deficiencies, the use of the payback method is therefore not entirely irrational.
\end{abstract}

\begin{abstract}
Die terugbetalingstydperk is een van die metodes wat in die praktyk die meeste vir die evaluering van kapitaalinvesteringsprojekte gebruik word, ten spyte van die kritiek wat teen die benadering geopper word. Die metode se belangrikste voordeel is dat dit eenvoudig is en min berekeninge vereis. ' $n$ Ongesofistikeerde metode soos die terugbetalingstydperk kan ook tot die regte investeringsbesluit lei indien die korrekte terugbetalingsmaatstaf voorgeskryf word. In hierdie artikel word die optimum terugbetalingsmaatstaf en hoe inflasie dit beïnvloed, ontleed. Drie verskillende maniere om die terugbetalingstydperk tydens inflasie te bereken, word ondersoek. In elke geval hang die optimum terugbetalingsmaatstaf af van die tipe bates (bedryfsbates, bates onderhewig aan waardevermindering en bates waarvan die waarde nie verminder nie), en ook van die leeftyd van die bates wat in waarde verminder. Die ondersoek toon dat die optimum nominale terugbetalingsmaatstaf (gebaseer op nominale kontantvloei) afneem met toenemende inflasie vir alle tipe bates. Inflasie beïnvloed nie die optimum reële terugbetalingsmaatstaf (gebaseer op nominale kontantvloei vir inflasie aangepas) nie. 'n Terugbetalingsmaatstaf wat inflasie ignoreer neem baie vinnig af met toenemende inflasie indien 'n projek bedryfsbates benut. In dié artikel word getoon dat daar 'n ingewikkelde maar sistematiese verhouding bestaan tussen ' $n$ projek se terugbetalingstydperk en sy opbrengs. Ten spyte van die nadele van hierdie metode is die gebruik van die terugbetalingstydperk dus nie heeltemal sonder regverdiging nie.
\end{abstract}

\section{Introduction}

It is generally accepted that the payback method of investment appraisal suffers from some serious deficiencies. The criticisms of the method can be found in any financial text, and usually include that the method gives equal weight to all the cash flows before the payback period and no weight to cash flows after it. In so doing it disregards the time value of money. Once the payback period has been determined it has to be compared with some yardstick to determine whether to accept or reject a project. Many firms that use payback choose the cut-off essentially by guesswork (Brealey and Myers, 1988: 74).

Despite all the criticism against it, payback is one of the most commonly used methods of investment appraisal. In a survey of 103 firms in the United States, Gitman and Forrester (1977: 277) found that 10 percent of firms use payback as their primary decision criterion, and a further 44 percent use it as their second most important criterion. Another United States survey found payback to be the capital budgeting method most frequently used by the 189 respondents. It is used by 74 percent of respondents, usually in combination with other methods (Schall, Sundem and Geijsbeek, 1978: 282). A later survey of 58 American firms that also operated in foreign countries found that 10 percent of firms use this as their primary decision criterion, while a further 62 percent use it as a secondary criterion (Oblak and Helm, 1980: 277). In the United Kingdom, a survey undertaken for the Institute of Chartered Accountants in England and Wales found that 86 percent of respondents employ the payback method for investment appraisal (Westwick and Shohet, 1976: 10).

In South Africa Lambrechts (1976: 28) found that payback is used by 63 percent of the 48 companies in his sample. In a later survey of 132 South African firms, Andrews and Butler (1986: 33) found that 69 percent of firms use the payback method in capital budgeting. For 26 percent of the firms payback is the most important capital budgeting method in use.

The question remains why the unsophisticated and inaccurate payback method is used so often in practice. It is generally agreed that the simplicity of the payback method is one of its chief advantages. Sarnat and Levy (1969: 489) also point out that the use of a crude method of profitability need not necessarily result in decision errors. If the correct payback cut-off is specified, the method will provide the correct capital budgeting decision. Deciding on the payback cut-off is therefore critical when using the payback method. In this paper the optimum payback cut-off and how this changes under inflation is studied. The effect of inflation on the optimum cut-off is important for firms using this method under high inflation. It is also important for firms operating in a period of low inflation following after periods of high inflation. This is so because many firms arrive at the payback cut-off essentially by guesswork (Brealey and Myers, 1988: 74). If the optimal cut-off is influenced by inflation, practices that were successful under high inflation may now turn out to be inappropriate. It is 
therefore necessary to understand the effect of inflation on the optimal payback cut-off so that firms can make the necessary adjustments when moving from a position of high inflation to one of low inflation or vice versa.

The paper is in six parts. This section contains the introduction to the paper, and in the next section the optimal payback cut-off in the absence of inflation is discussed. In the next three sections the influence of inflation on the optimum cut-offs of the nominal payback, real payback and uninflated payback methods are respectively studied. Conclusions are presented in the last section.

\section{Optimal payback cut-off in the absence of inflation}

The relationship between the payback period of a project and its internal rate of return (IRR) has already been studied by Gordon in 1959. Gordon was looking for ways to estimate the IRR of a project, and he noted that:

'(The IRR) is rarely if ever used to evaluate equipment proposals for two complementary reasons. First, solving the equation for (the IRR) involves tedious trial-and-error calculations, and, second, the range of error in the estimate of future receipts is considerable. The limitations of the basic data appear, therefore, to make it unwise to spend considerable effort in using a correct but difficult formula' (Gordon, 1959: 49).

Today it is still difficult to estimate distant cash flows. Calculating the IRR presents much less of a difficulty since even inexpensive pocket calculators have the ability to solve for the IRR at the push of a button. In 1959 pocket calculators still had to be invented, and Gordon was looking for a short-cut estimate of the IRR. He found that the reciprocal of the payback period was in fact an estimate of a project's IRR. For long-lived assets it provided the best estimate among the methods that he considered (Gordon, 1959: 49).

The relationship between the payback period and IRR as determined by Gordon can also be used to determine an optimal payback cut-off period. Gordon considered projects with a single initial investment followed by constant annual earnings or savings. Assets are assumed to have a zero scrap value. For these projects, the optimal payback cut-off is:

$p=\left(\frac{1}{r}\right)-\left(\frac{1}{r \cdot(1+r)^{d}}\right)$

where:

$\mathrm{p}=$ optimal payback cut-off

$\mathbf{r}=$ discount rate

$\mathrm{d}=$ project life

Equation (1) is the familiar expression for the present value of an annuity. The second term in equation (1) above will decrease with increasing project length. The optimum payback cut-off will therefore approach the reciprocal of the discount rate for long projects. For shorter projects the optimum payback cut-off will be shorter than the reciprocal of the discount rate. No project should therefore be accepted that has a payback period longer than the reciprocal of the discount rate. An even shorter payback period should be required if the project is short lived.

The next section of this paper will investigate how equation (1) should be adapted to calculate the optimum payback cut-off under inflation.

\section{Optimum nominal payback cut-off under inflatlon}

The expression for the optimum payback cut-off in equation (1) has been developed in the absence of inflation. Inflation changes the optimum cut-off period for the following three reasons:

- Under inflation, the annual earnings or savings provided by a project will not be constant, but will increase at the inflation rate. The model must therefore allow for escalating earnings or savings. All other things being equal, escalating eamings or savings means that initial benefits could be lower while the project still has an acceptable retum. This will result in a longer optimal payback cutoff.

- Inflation increases the nominal return required and therefore the discount rate to be used. All other things being equal, this would result in a shorter optimal payback cut-off.

- Inflation affects the cash flows associated with different types of assets differently. Under inflation, the nominal value of non-depreciable assets (such as land) increase, resulting in a large cash inflow when the project is wound up. The project therefore requires lower annual returns to show an acceptable return. All other things being equal, this will result in a longer optimal payback cut-off. Current assets, on the other hand, has to be replaced continually at inflated prices. If this is not taken into account when determining the cash flows of a project, the cash flows are overstated, and a shorter payback (in terms of the overstated cash flows) is required if the project is to have an acceptable overall retum.

The remainder of this paper studies the combined effect of these influences on the optimal payback cut-off. This section investigates the effect when using the nominal payback method (all cash flows expressed in nominal money terms). To determine the optimum payback cut-off, a theoretical project is considered and the relationship between the project's IRR and its payback period determined. The optimum payback cut-off is the payback period of a marginal project (a project with an IRR equal to the project discount rate).

Apart from changes affected by inflation, this study follows the assumptions of the studies by Gordon (1959) and Sarnat and Levy (1969) as closely as possible. Like the previous studies, this study also employs a discrete time analysis in which all trading takes place at the end of each year. Samat and Levy (1969: 480) assume 'equal annual net receipts', and Gordon (1959: 48) assumes that a project's 'savings in each year will be the same'. The present study, similarly, assumes that annual tumover, cost of sales and cash expenses stay constant in real terms for the duration of the project.

Both the previous studies assume that a project requires a single investment outlay in year 0 . Sarnat and Levy (1969: 480) refer to the 'investment outlay', while Gordon 
(1959: 48) calls it the 'cost of the proposal'. The present study also assumes that a single investment in assets is made in year 0 of the project. It differs from the previous studies in that they assume investment in depreciable assets only, while the present study assumes that the project requires investment in current, depreciable and non-depreciable assets. The present study, like the previous studies, assumes that no further investment in depreciable or nondepreciable assets is made during the remainder of the project. It does however assume that a constant real level of current assets has to be maintained over the life of the project. The level of current assets therefore increases at the inflation rate, and this requires an annual additional investment in current assets for the duration of the project.

Sarnat and Levy (1969: 480) assume 'zero terminal values', while Gordon (1959: 48) claims that 'it is ... common to ignore the equipment's scrap value'. The present study also assumes a zero scrap value for depreciable assets. Current and non-depreciable assets are converted to cash at the termination of the project and this value added to the project cash flow.

The derivation of the relationship between a project's IRR and its annual cash flows is presented in Appendix 1. This derivation identifies the annual cash flows of a project. It determines what the relationship between the annual cash flows need to be to give the project its assumed IRR. With this known, the project's payback period can be calculated.

Using the relationships established in Appendix 1, the nominal payback period of a marginal project is calculated in Appendix 2. The nominal payback period is the time it takes for the initial investment of the project to be repaid in nominal money terms.

The derivation in Appendix 2 provides the following expression for the nominal payback period:

$$
P_{n}=\log \left(1+\frac{i \cdot\left(C A_{0}+D A_{\hat{o}}+N A_{\hat{o}}\right)}{(r-i) \cdot\left(C A_{0}+\frac{D A_{\hat{o}}}{1-((1+i) /(1+r))^{d}}+N A_{\hat{b}}\right)}\right) / \log (1+i)
$$

where:

p. = nominal payback period

i $=$ inflation rate

r = internal rate of return of the project

$\mathrm{CA}_{\mathrm{O}}=$ current assets at the end of year 0 of the project

$\mathrm{DA}_{\hat{O}}^{\hat{~}}=$ depreciable assets acquired during year 0 of the project

$\mathrm{NA}_{\hat{O}}^{\hat{~}}=$ non-depreciable assets acquired during year 0 of the project

Equation (2) can be used to determine the optimal payback cut-off for any project, also when the project employs a combination of the three different types of assets. To determine the payback cut-off, one simply substitutes the proportion invested in each of the three asset types, the inflation rate and the appropriate nominal discount rate into equation (2). This yields the payback period of a marginal project. Projects with a longer payback period should be rejected, and projects with a shorter period accepted.

To study the relationships in equation (2) it is easier to consider single asset projects. These are projects employing only current assets, only depreciable assets or only nondepreciable assets.

This is done in Appendix 2, which shows that for a 100 percent current asset project or a 100 percent non-depreciable asset project:

$p_{n}=\left(\frac{\log \left(1+\frac{i}{r-i}\right)}{\log (1+i)}\right)$

For a 100 percent depreciable asset project:

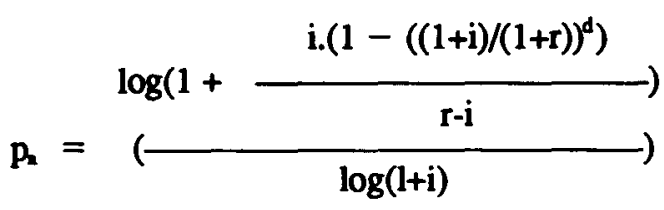

To determine the effect of inflation on the payback cut-off one further assumption is required. This concems the effect of the inflation rate $i$ on the discount rate $r$. The discount rate $r$ depends upon the risk characteristics of the project, and the correct rate would be the market capitalisation rate of projects or firms of similar risk. Opinions differ about the effect of inflation on the market capitalisation rate.

Fisher (1930: 43) studied the effect of inflation on real returns and expects that nominal returns will adjust to keep real returns constant. Fama (1981) and Benderly and Zwick (1985) have however found a negative relationship between the rate of inflation and the real yield of shares on the New York Stock Exchange. Fama believed this to be a spurious relationship because it contradicts rational expectations, according to which real variables should not be influenced by purely nominal variables such as the inflation rate. Benderly and $Z$ wick attempted to explain this relationship in terms of real balances.

The debate on the effect of inflation on real returns falls outside of the scope of this paper, although a relationship of this nature may of course have an additional effect on the optimal payback cut-off. For the purpose of the present analysis the rational expectations position will be accepted according to which real returns are not affected by the rate of inflation.

The effect of inflation on the optimal payback cut-off can now be determined by assuming a constant real return and calculating the optimal payback cut-off for different inflation rates using equations (3) and (4). This has been done for a real return of 10 percent and the results are shown in Figure 1.

The curves in Figure 1 show the optimal payback cut-off for current and non-depreciable assets (the top curve) and depreciable assets with a life of 20 years, 10 years and 5 years respectively.

The $y$-axis intercepts of the curves in Figure 1 show the optimal payback cut-offs in the absence of inflation. These correspond to the cut-offs calculated by Gordon (1959) and Sarnat and Levy (1969) using equation (1). It is clear from Figure 1 that the optimum cut-off varies with the life of 


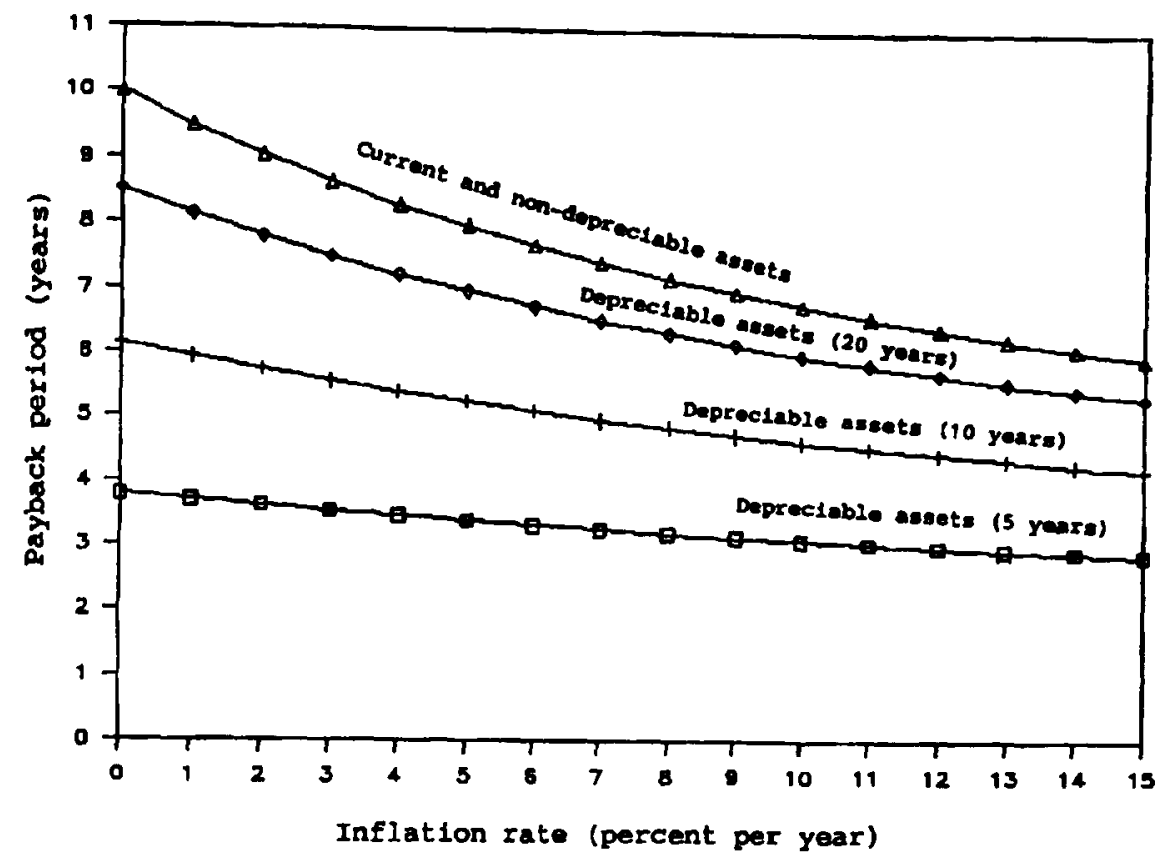

Figure 1 The optimal nominal payback cut-off for projects with a required real retum of 10 percent per year

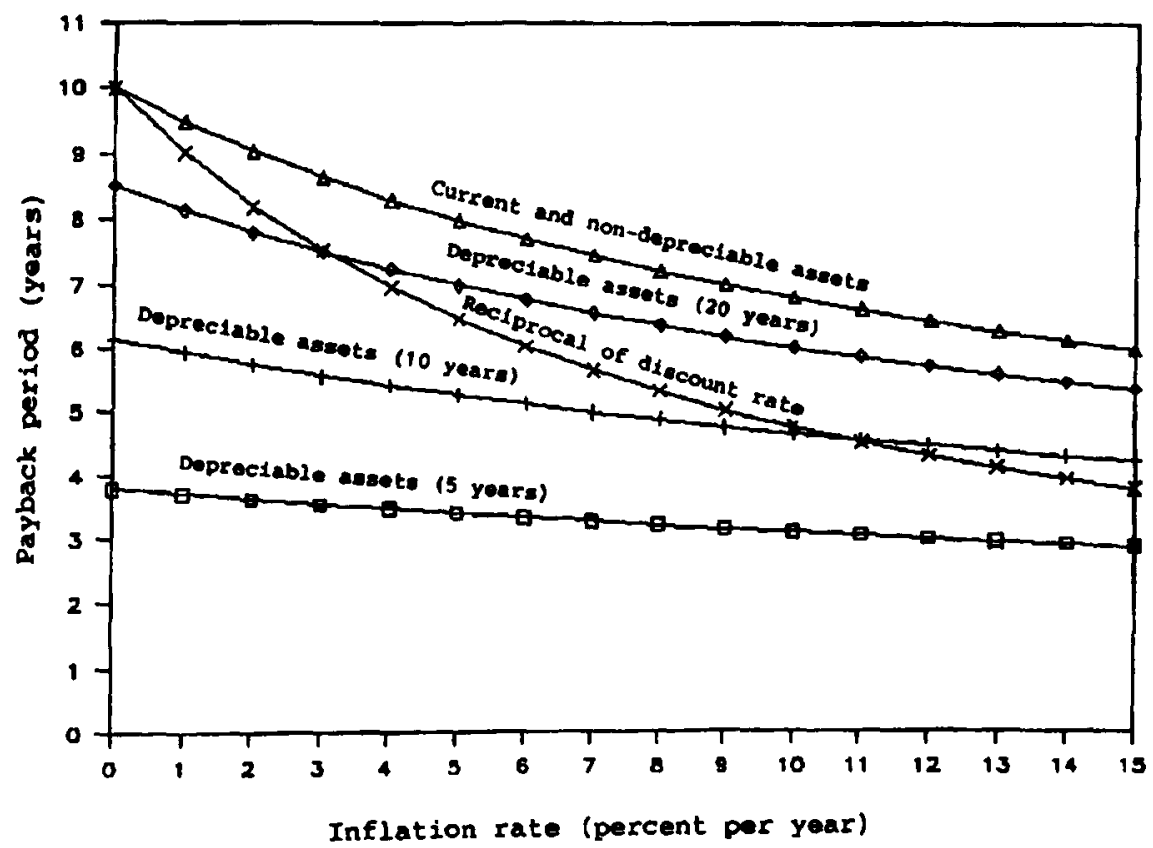

Figure 2 The optimal nominal payback cut-off and discount rate reciprocal for projects with a required real return of 10 percent per year

depreciable assets, and that the optimum cut-off is longer for long lived than for short lived assets.

Figure 1 also shows that inflation shortens the optimum nominal payback cut-off for all projects. A firm operating under inflation should therefore require projects to have a shorter nominal payback period than in the absence of inflation. Similarly, a firm operating under low inflation should relax its payback requirement if this has been established in a period of high inflation.

Gordon (1959: 49) found that, in the absence of inflation, the reciprocal of the payback period was an estimate of a project's IRR. This relationship can also be used to select a payback cut-off. The optimum payback cut-off approaches the reciprocal of the required rate of return for long projects. For shorter projects the optimum payback cut-off is shorter than the reciprocal of the required rate of return.

In Figure 2 is illustrated the effect of inflation on the relationship between the optimum payback cut-off and the reciprocal of the required rate of return. It shows that the reciprocal of the required rate decreases more rapidly than the optimum payback cut-offs. In the absence of inflation all the optimum payback cut-off points were shorter than or 
equal to the reciprocal of the required rate. Firms can therefore use the reciprocal of the required rate as an appropriate cut-off when using payback for the initial evaluation of projects. This criterion is less strict than optimal, and firms can use this to eliminate some inferior projects and produce a shorter list of projects warranting closer attention. Under inflation this relationship does not hold any longer, and using the reciprocal of the required rate as a cut-off could result in eliminating acceptable projects.

The results presented in Figures 1 and 2 as well as the analyses on which these have been based refer to a nominal payback period. In this the effect of inflation has been taken into account when calculating the annual cash flows on which the payback calculation is based. In the next sections payback calculations that do not take the effect of inflation into account will be considered.

\section{Real payback period and its optimal cut-off}

The correct procedure to calculate the real payback period is to determine the actual nominal project cash flows, deflate this and use the deflated cash flows to calculate the payback period. The derivation of this optimum real payback cut-off is shown in Appendix 3, which provides the following expression for the optimum cut-off.

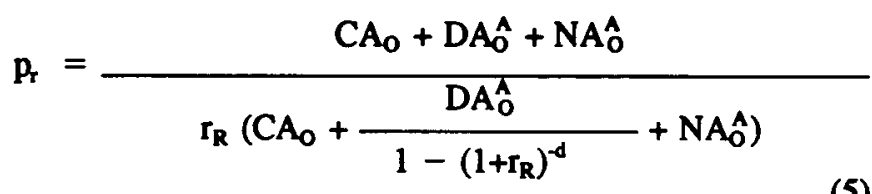

where:

$\mathrm{p}_{\mathrm{r}}=$ real payback period

$\mathbf{r}_{\mathbf{R}}=$ real rate of return of the project (internal rate of return for cash flows expressed in real money terms)

The optimum payback cut-off for single asset projects are also calculated in Appendix 3. For the 100 percent current asset and the 100 percent non-depreciable asset projects this is given by:

$\mathbf{p}_{\mathbf{r}}=\frac{1}{\mathbf{r}_{\mathrm{R}}}$

And for 100 percent depreciable asset projects:

$$
p_{z}=\left(\frac{1}{r_{R}}\right)-\left(\frac{1}{r_{R} \cdot\left(1+r_{R}\right)^{d}}\right)
$$

Equation (7) is similar to equation (1), used by Gordon (1959) and Samat and Levy (1969) to calculate optimal cutoffs in the absence of inflation.

As is clear from equations (5), (6) and (7), the real payback cut-off does not depend upon the rate of inflation. This method therefore has an important advantage over the nominal payback method because firms need not adjust the payback yardstick with changing inflation. The method's main disadvantage is that it requires more calculations than the nominal payback. To use the method, the analyst has to estimate nominal cash flows and has to convert these to real cash flows. The analyst may attempt to overcome this disadvantage by estimating the real cash flows directly. This will result in the calculation of an uninflated payback period, which is different from the real payback. This is discussed in the next section.

\section{Uninflated payback period and its optimal cut-off}

Firms operating under inflation will not always take the effect of inflation into account when calculating payback periods. Simplicity of calculation is one of the main advantages of the payback method. Complicated calculations to determine the exact effect of inflation on future project cash flows, seem inappropriate in this context. Andrews and Butler (1982: 35) have found that 42 percent of firms in South Africa make no allowances for inflation in capital budgeting. It is fair to assume that this percentage will be even larger if one considers only those firms who use the unsophisticated payback method.

A project's annual cash flows (for detail see Table A.1.1) consist of two elements. The first is the annual trading surplus (sales minus cash expenses minus inventory processed). The second element is the annual investment in current assets required under inflation to keep the real level of current assets constant. The first element is easily determined but the second element is not visible when inflation is ignored. Without inflation current assets stay constant for the duration of a project. It appears as if no investment in current assets is required when inflation is ignored.

When no allowances is made for inflation, analysts will therefore calculate what we shall call an 'uninflated payback period'. In calculating the uninflated payback, analysts will assume that the cash flow in the first year consists of the trading surplus in that year. They will furthermore assume that annual project cash flows remain constant for the duration of the project.

The derivation of the optimum uninflated payback cut-off is shown in Appendix 4. This provides the following expression for the uninflated payback period:

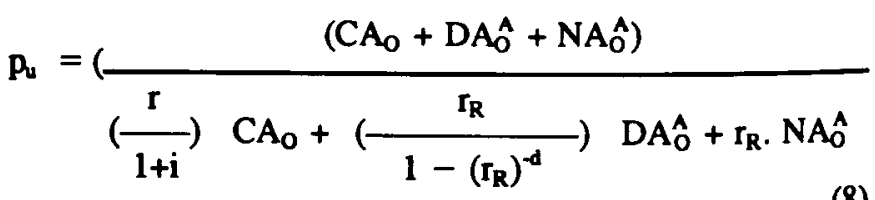

The uninflated payback cut-off in equation (8), unlike the real payback cut-off shown in equation (5), varies with the inflation rate. To study the difference between these two methods it is easier to consider single asset projects. The derivation in Appendix 4 yields the following optimum uninflated payback cut-off for a 100 percent non-depreciable asset project:

$$
p_{u}=\frac{1}{r_{R}}
$$


and for the 100 percent depreciable asset project:

$p_{u}=\left(\frac{1}{r_{R}}\right)-\left(\frac{1}{I_{R} \cdot\left(1+r_{R}\right)^{d}}\right)$

The uninflated payback cut-offs in equations (9) and (10) are identical to the real payback cut-offs presented in equations (6) and (7). These two methods do not differ for projects employing only depreciable and non-depreciable assets.

From Appendix 4 the optimum payback cut-off for the 100 percent current asset project is:

$p_{v}=\left(\frac{1+i}{r}\right)$

For projects employing current assets, the uninflated payback cut-off varies with the rate of inflation. This is also evident from Figure 3, where the effect of inflation on the optimum uninflated payback cut-off is shown.

Figure 3 shows that inflation has a marked effect on the optimum uninflated payback cut-off of project employing only current assets. The optimum payback decreases sharply with inflation. This can be ascribed to the fact that the uninflated payback period does not take the annual investment in current assets required under inflation into account.

The results illustrate the importance of current asset investment during times of inflation. When this is neglected, the cash flows resulting from the project is seriously overstated. When calculating payback periods this results in requiring a very much shorter payback period in terms of the overstated cash flows.

\section{Conclusions}

This study investigated the effect of inflation on the optimum cut-off when using three different methods of calculating project payback under inflation.

The nominal payback method uses nominal (inflated) cash flows to determine the project payback. The study shows that inflation shortens the optimum nominal payback cut-off for all projects. A firm operating under inflation should therefore require projects to have shorter nominal payback periods than in the absence of inflation. Similarly, a firm operating under low inflation should relax its payback requirement if this has been established in a period of high inflation. Although the optimum nominal cut-off decreases, it does not decrease as rapidly as the reciprocal of the discount rate. The latter is sometimes used as the payback cut-off. Under inflation, acceptable projects may therefore have payback periods longer than the discount rate reciprocal. This does not happen in the absence of inflation.

The real payback method deflates the nominal cash flows before determining the project payback. The study shows that the optimum real payback cut-off is not influenced by inflation, and that the optimum cut-off determined by Gordon (1959) still hold under inflation for this method.

The real payback method is based on nominal cash flows that are subsequently deflated. If analysts try to reduce the amount of calculation this requires and simply ignores the effects of inflation, they will calculate what we have called the 'uninflated payback'. This does not include the additional investment in current assets required under inflation. The analyses show that the optimum uninflated payback cut-off is shortened by inflation for projects employing current assets.

Gordon (1959) has shown that the life of assets employed has an effect in the absence of inflation on the optimum payback cut-off. This study confirmed that this holds under

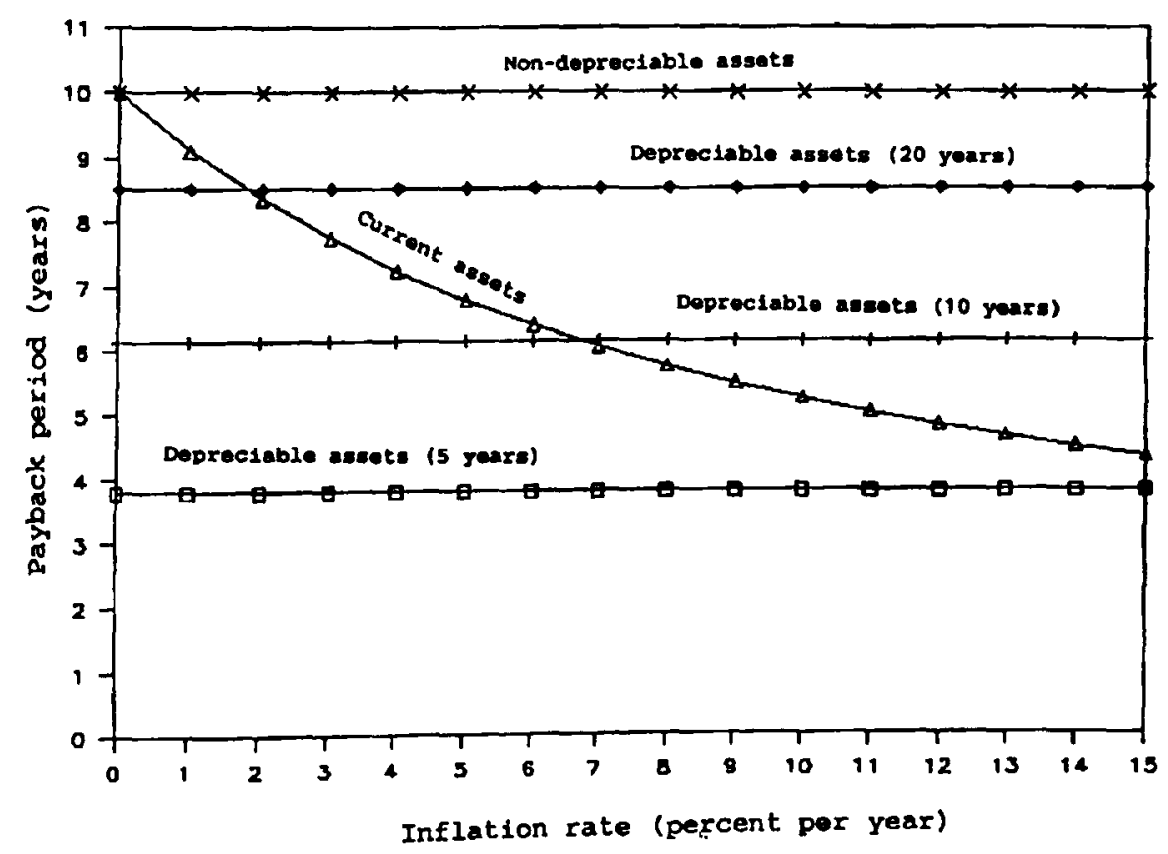

Figure 3 The optimal uninflated payback cut-off for projects with a required real return of 10 percent per year 
inflation as well, and expanded the amalysis to show the effects of employing current and non-depreciable assets. The study shows the importance of the type of assets employed when determining the optimum payback cut-off.

This study shows that although the relationships between the discount rate and required payback periods are at times complex, they are consistent. These relationships should not be generalised because they are limited by the assumptions about cash flow patterns on which the derivations have been based. The systematic relationships nevertheless illustrate that the use of payback is not entirely irrational. The method's simplicity and ease of calculation compensates for ins deficiencies and could pardy explain its wide acceptance in practice.

\section{Let of symbots used}

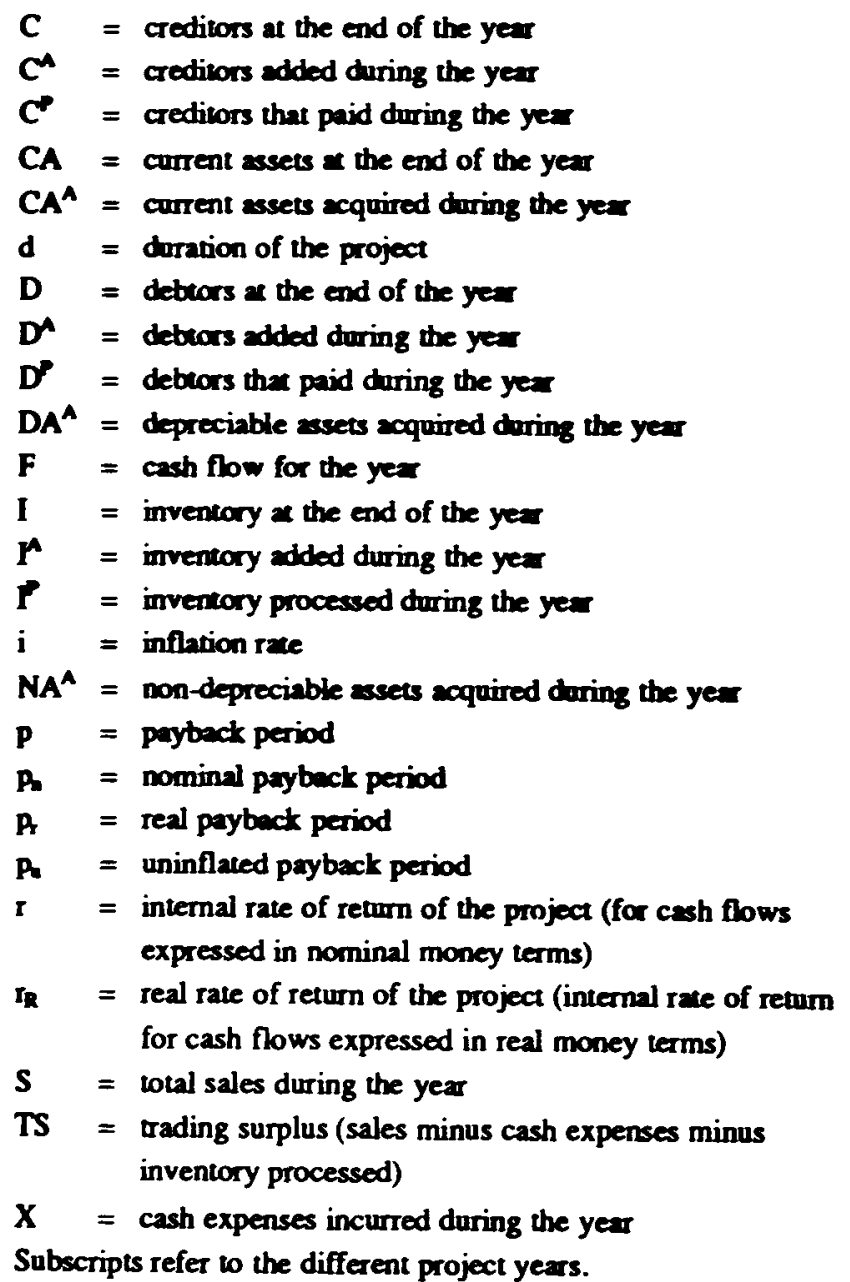

\section{References}

Andrews, G.S. \& Butler, F. 1986. Criteria for major investment decisions. The Investment Analysts Journal, May, 31-37.

Benderly, J. and Zwick, B. 1985. Inflation and real balances, ouput and real stock returns. American Economic Review, Vol. 75, December, 1115-1123.

Brealey, B.A. and Myers, S.C. 1988. Principles of corporace finarce. Third ed. New York: MoGraw-Hill.

Fama, E.F. 1981. Slock retums, real activity, inflation and money. American Economic Review, Vol. 71, September, 545-564.

Fisher, I. 1930. The theory of interest. New York: Macmillan.
Gitman, LJ. \& Forrester, J.R. 1977. A survey of capital budgeting techniques used by major U.S. firms. Financial Maragement, Fall, 67-71.

Gordon, MJ. 1955. The payoff period and the rate of profit. J. Bus., October, 253-260, reprinted in The Managemens of Corporate Capival. (E. Solomon, Ed.) 1959, Glencoe, Ilinoir: The Free Press.

Lembrechts, IJ. 1976. The practice of capital investment decision-making in South Africa. The Investment Andysts Jownd, Vol. 8, August, 27-31.

Oblak, DJ. \& Helm, RJ. 1980. Survey and analysis of capital budgeting methods used by multinationals. Fin. Manage., Winter, 37-41.

Samat, M. \& Levy, H. 1969. The relationship of nules of thumb to the internal rate of return: A restatement and generalization. The Jownal of Finance, Vol. 24, 479-489.

Schall, L.D., Sundem, G.L. \& Geijsbeek, W.R. 1978. Survey and analysis of capital budgeting methods. The Jownal of Finance, Vol. 33, March, 281-287.

Westwick, C.A. \& Shohet, P.S.D. 1976. Investment appraisal and inflation. The Institute of Chartered Accountants in England and Wales Research Committee Occasional Paper no.7.

Appendix 1 Derivation of the relationship between a project's IRR and its annual cash flows

\section{Project cash flows}

The annual cash flow associated with a project can be expressed as:

$\mathrm{F}_{\mathrm{z}} \quad$ = (cash received during year $\mathrm{n}$ of the project) minus (cash paid our during year $\mathrm{n}$ of the project)

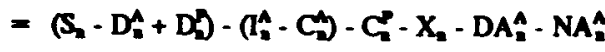

During any year of the project we also have that:

$D_{1}=D_{n-1}+D_{n}^{A}-D_{n}^{P}$

$C_{1}=C_{n-1}+C_{n}^{\mu} \cdot C_{n}^{P}$

$\mathbf{L}=\mathbf{I}_{\mathbf{n}-1}+\mathbf{I}_{\mathrm{a}}^{\mathbf{A}}-\mathbf{I}_{\mathbf{p}}^{\mathbf{P}}$

For year 0 of the project (the year in which the project is initiated):

$D_{-1}=C_{.1}=I_{1}=0$

Substituting into (2), rearrenging and substituting into (1):

$F_{0}=-C_{0}-D A_{0}-N A_{0}$

During any year $j$ of the project (where $j$ is greater than 0 and smaller than d):

$\mathrm{DA}_{\mathbf{j}}^{\hat{\mathbf{j}}}=\mathbf{N} \mathbf{A}_{\mathbf{j}}^{\hat{\mathbf{n}}}=\mathbf{O}$

and

$D_{i}=(1+i) D_{1}$ 
so that, by substituting into (2):

$D_{j}^{A}=i D_{j-1}-D_{j}^{p}$

Becausc of a trading pattern that stays constant in real terms we have that:

$D_{j-1}=(1+i)^{j-1} D_{0}$

Substituting into (5):

$D_{j}^{\Lambda}=i(1+i)^{j-1} D_{0}-D_{j}^{p}$

Similarly for creditors and inventory:

$C_{j}^{\wedge}=i(1+i)^{-1} C_{0}-C_{j}^{P}$

$\mathbf{I}_{j}^{\mathbf{A}}=\mathrm{i}(1+\mathrm{i})^{\mathrm{j}-1} \mathrm{I}_{\mathbf{O}}-\mathbf{I}_{\mathbf{j}}^{\mathrm{P}}$

Substituting this as well as (4) into (1) and rearranging:

$F_{j}=S_{j}-X_{j}-L_{j}^{P}-i(1+i)^{j-1} C A_{0}$

From the regular project trading pattem we also have that:

$S_{j}=(1+i) \quad S_{1}$

$X_{j}=(1+i)^{j-1} X_{1}$

$I_{j}^{p}=(1+i)_{j-1} I_{1}^{p}$

If we further define the trading surplus to be:

$\mathrm{TS}_{\mathrm{j}}=\mathrm{S}_{\mathrm{j}}-\mathrm{X}_{\mathrm{j}}-\mathrm{I}_{\mathrm{j}}^{\mathrm{P}}$

Then, substituting into (6) and rearranging:

$F_{j}=(1+i)^{-1} T S_{1}-i(1+i)^{j-1} C A_{0}$

In the last year of the project (year d), the wound-up value of nondepreciable and current assets has to be taken into account in addition to the trading cash flow. Adding this to the expression derived in equation (7), we obtain:

$F_{d}=(1+i)^{d-1} T S_{1}-i(1+i)^{d-1} C A_{0}+(1+i)^{d}\left(C A_{0}+N A_{0}\right)$

The cash now in any ycar of the project can therefore be determined from equations (3), (7) and (8) and are summarised in Table A.1.1.

Trading surplus required

It is assumed that the project has an internal rate of return of $r$, or that:

$$
\sum_{j=0}^{d} \frac{P_{j}}{(1+r)^{3}}=0
$$

Table A.1.1 Project cash flows

\begin{tabular}{|c|c|c|c|}
\hline $\begin{array}{l}\text { Cash flow } \\
\text { item }\end{array}$ & $\begin{array}{c}\text { Year O (ini- } \\
\text { tial year) }\end{array}$ & Year j $(0<j<d)$ & Year d (last year) \\
\hline $\begin{array}{l}\text { Initial } \\
\text { investment }\end{array}$ & $\begin{array}{l}-\mathbf{C A}_{\mathbf{0}} \\
-\mathbf{D A} \hat{\mathbf{O}} \\
-\mathbf{N A} \mathbf{A}_{\mathbf{O}}\end{array}$ & $\mathbf{O}$ & $\mathbf{0}$ \\
\hline $\begin{array}{l}\text { Trading } \\
\text { surplus }\end{array}$ & 0 & $(1+i)^{-1} \mathrm{TS}_{1}$ & $(1+\mathrm{i})^{d-1} \mathrm{TS}_{1}$ \\
\hline $\begin{array}{l}\text { Additional } \\
\text { current assets }\end{array}$ & o & $-i(1+i)^{j-1} C A_{0}$ & $-i(1+i)^{L 1} C A_{0}$ \\
\hline Wound up & O & $\mathbf{0}$ & $\begin{array}{l}-(1+i)^{d}\left(C A_{0}\right) \\
-(1+i)^{d}\left(N^{A} A_{0}^{A}\right)\end{array}$ \\
\hline
\end{tabular}

Substituting for the annual cash flows from equations (3), (7) and (8):

$$
\begin{aligned}
& \sum_{j=0}^{d} \frac{x_{j}}{(1+x)^{3}} \\
& -\left(-c a_{0}-D a_{0}^{A}-m a_{0}^{A}\right)\left(\frac{1}{1+x}\right)^{0} \\
& +\sum_{j=1}^{d-1}\left((1+1)^{j-1} \mathrm{rs},-1(1+i)^{j-1} \mathrm{Ca_{0 }}\right)\left(\frac{1}{1+r}\right)^{j} \\
& \text { - }\left((1+1)^{d-1} \mathrm{Ts},-1(1+i)^{d-1} c a_{0}\right)\left(\frac{1}{1+\varepsilon}\right)^{a} \\
& +(1+i)^{d}\left(C a_{0}+N A_{0}^{A}\right)(\underset{1+x}{1}) d \\
& =0
\end{aligned}
$$

And therefore:

$$
\begin{aligned}
& -C \lambda_{0}-0 A_{0}^{\lambda}-w A_{0}^{A}+\sum_{j=1}^{d}\left(\frac{1+1}{i+x}\right) i\left(\frac{T S_{1}}{(1+1)}-\frac{1 C \lambda_{0}}{(1+1)}\right) \\
& +\left(C a_{0}+N a_{0}^{A}\right)(\underset{1+\varepsilon}{1+i}) d=0
\end{aligned}
$$

Solving for $\mathrm{TS}_{1}$ gives:

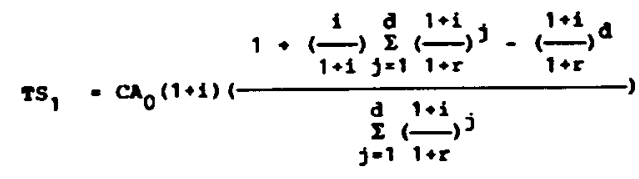

$$
\text { - } \operatorname{on}_{0}^{A}(1+1)\left(\frac{1}{\sum\left(\frac{1+1}{1+x}\right)}\right)
$$

$$
+\operatorname{man}_{0}^{A}(1+1)\left(\frac{1-\left(\frac{1+1}{1+x}\right)}{\sum_{j=1}^{d}\left(\frac{1+i}{1+x}\right)^{j}}\right)
$$


But:

$$
\sum_{j=1}^{d}\left(\sum_{1+x}^{1+1}\right) j=\frac{\frac{1+1}{1+x}-\left(\frac{1+1}{1+x}\right)^{d+1}}{1-\frac{1+1}{1+x}}
$$

Substituting and rcarranging:

$$
2 s_{1}=r C A_{0}+\left(\frac{x-1}{1-\left(\frac{1+i}{1+r}\right) d}\right) D A_{0}^{A}+(r-1) N A_{0}^{A}
$$

\section{Appendix 2 Calculating the optimum nominal} payback cut-off

The payback period of a project is the time it takes for the original investment to be repaid (in nominal money terms). For a payback period of $p$ therefore:

$$
\sum_{j=0}^{p} \mathbf{r}_{j}=0
$$

By substituting for the annual cash flows of the marginal project the payback period of the marginal project can be calculated. This can then be used as the cut-off period for payback evaluation. Substituting from equations ( 3 ) and (7):

$$
\begin{aligned}
& \sum_{j=0}^{p} F_{1} \\
& =-C A_{0}-D A_{0}^{\lambda}-N A_{0}^{A}+\sum_{j=1}^{p}\left((1+1)^{j-1} T S_{1}-1(1+1)^{j-1} C A_{0}\right) \\
& =0
\end{aligned}
$$

Substituting for the annual trading surplus from (10) and rearranging:

$$
\begin{aligned}
& -c a_{0}-m A_{0}^{\lambda}-m A_{0}^{A} \\
& \text { - } \sum_{j=1}^{p_{n}}\left((1+1)^{j-1}\right)\left((x-1) \mathrm{C}_{0}+\left(\frac{x-1}{1-\left(\frac{1+1}{1+x}\right) \mathrm{d}}\right) \mathrm{D} \lambda_{0}^{\lambda}+(x-i) N \lambda_{0}^{A}\right) \\
& =0
\end{aligned}
$$

So that:

$$
(1+1)^{D_{n}}-1+\frac{1 \cdot\left(C A_{0}+D A_{0}^{A}+N A_{0}^{A}\right)}{(x-1) \cdot\left(C A_{0}+\frac{D A_{0}^{A}}{1-((1+1) /(1+r))^{d}}+N A_{0}^{A}\right)}
$$

And therefore:

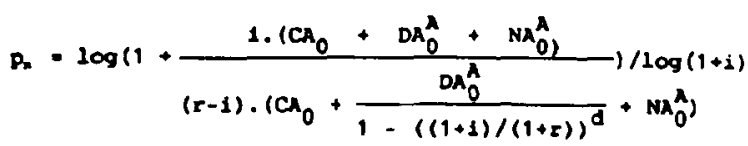

Nominal payback cut-off for single asset projects

For the 100 percent asset project:

$$
\mathrm{DA}_{0}^{\mathbf{A}} \cdot \mathrm{NA}_{0}^{\mathbf{A}}=0
$$

Substituting into (12) and simplifying:

$$
P_{n}=\frac{\log \left(1+\frac{1}{x-1}\right)}{\log (1+1)}
$$

Similarly for 100 percent non-depreciable asset projects. For the 100 percent depreciable asset project:

$$
\mathrm{Ca}_{0}=\mathrm{NA}_{0}^{\lambda}=0
$$

Substituting into (12) and simplifying:

$$
\text { P. }-\frac{\log \left(1+\frac{1 .(1-((1+1) /(1+x)) d}{x-1}\right)}{\log (1+i)}
$$

\section{Nominal payback cut-off in the absence of inflation}

In the absence of inflation ( $i=0)$ the relationship presented in equation (11) still applies. The derivations following equation (11) have assumed that $i \neq 0$. The results therefore do not apply in the absence of inflation. To determine the relationships when $i=0$ substitute into (11):

$$
C A_{0}+D A_{0}^{A}+N A_{0}^{A}=A n \cdot r \cdot\left(C A_{0}+\left(\frac{1}{1-(1+\Gamma)^{-d}}\right) D A_{0}^{A}+N A_{0}^{A}\right.
$$

$$
\sum_{j=1}^{p}\left((1+i)^{j-1}\right)=\frac{(1+1)^{p_{n}}-1}{1} \quad(i \neq 0)
$$

And therefore:

$$
p_{a}=\frac{C A_{0}+D A_{0}^{A}+N A_{0}^{A}}{x \cdot\left(C A_{0}+\left(\frac{1}{1-(1+x)^{-d}}\right) O A_{0}^{A}+N A_{0}^{A}\right.}
$$

For the 100 percent current asset firm:

$$
\mathrm{DA} \mathrm{A}_{0}^{A}=\mathrm{NA}=0
$$


Substituting into (15) and simplifying:

$$
\text { p. }=1 / 8
$$

Similarly for 100 percent non-depreciable asset firms.

For the $\mathbf{1 0 0}$ percent depreciable asset firm:

$$
c_{0}=\mathbf{w a}_{0}^{\hat{A}}=0
$$

Substituting into (15) and simplifying:

$$
D_{0}=\underset{r}{1}(1)\left(1-\left(\frac{1}{1+r}\right),\right.
$$

\section{Appendix 3 Calculating the optimum real payback cut-off}

The real payback period of a project is the time it takes for the original investment to be repaid (in year 0 money terms). For a payback period of $p$ therefore:

$$
\underset{j=0}{p_{x}} \frac{P_{1}}{(1+i)^{j}}
$$

By substituting for the annual cash flows of the marginal project the payback period of the marginal project can be calculated. This can then be used as the cut-off period for payback evaluation. Substituting from equations (3) and (7):

$$
\begin{aligned}
& \sum_{j=0}^{p_{i}} N_{j} \\
& =-C \lambda_{0}-D A_{0}^{A}-N A_{0}^{A}+\sum_{j=1}^{p_{k}} \frac{T S_{1}-1 \cdot C A_{0}}{(1+i)} \\
& =-C \lambda_{0}-D A_{0}^{A}-N A_{0}^{A}+p_{i}\left(\frac{T S_{1}}{(1+1)}-\frac{1 \cdot C A_{0}}{(1+1)}\right.
\end{aligned}
$$

Substituting for the annual trading surplus from (10) and rearranging:

$$
\begin{aligned}
& -C A_{0}-D A_{0}^{A}-N A_{0}^{A} \\
& +D_{r}\left(\frac{r-1}{1+i}\right)\left(C A_{0}+\left(\frac{1}{1-\left(\frac{1+1}{1+\Sigma}\right) d}\right) D A_{0}^{A}+N A_{0}^{A}\right)
\end{aligned}
$$$$
=0
$$

But:

$$
1+r=(1+1)\left(1+r_{R}\right)
$$

And therefore:

$$
\begin{aligned}
& \frac{1+r}{1+1}=1+r_{R} \\
& \frac{r-1}{1+1}=r_{R}
\end{aligned}
$$

Substituting into (11) and rearranging:

$$
\begin{aligned}
& D_{0} . x_{R}\left(C R_{0}+\frac{D A_{0}^{A}}{1-\left(1+x_{R}\right)^{-d}}+N u_{0}^{A}\right) \\
& -C a_{0}+D A_{0}^{A}+N A_{0}^{A}
\end{aligned}
$$

So that:

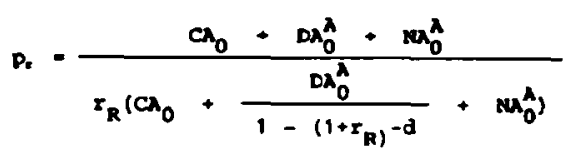

Real payback cut-off for single asset projects For the 100 percent current asset project:

$$
\mathrm{DA}_{0}^{\mathbf{\lambda}}=\mathrm{MA}_{0}^{\mathbf{\lambda}}=\mathbf{0}
$$

Substituting into (19) and simplifying:

$$
\text { pr }=\frac{1}{r_{R}}
$$

Similarly for 100 percent non-depreciable asset projects. For the 100 percent depreciable asset project:

$$
c a_{0}-s a_{0}^{n}=0
$$

Substituting into (19) and simplifying:

$$
p_{x}=\left(\frac{1}{r_{R}}\right)\left(\frac{1}{r_{R} \cdot\left(1+r_{R}\right)^{d}}\right)
$$

\section{Appendix 4 Calculating the optimum uninflated pay-} back cut-off

The uninflated payback period does not take the effect of inflation into account. The calculation assumes that the trading surplus remains constant over the life of the project. It differs from the real payback in that it does not take the cash flow caused by the additional investment in current assets into account. The annual cash flows are therefore assumed to be constant and equal to the annual trading surplus in year one (expressed in year 0 money terms).

For a payback period of $p$ therefore:

$$
-F_{0}=D_{0}\left(\frac{T s_{1}}{(1+1)}\right)
$$

Substituting for the initial investment from (3) and for the annual trading surplus from (10) and rearranging:

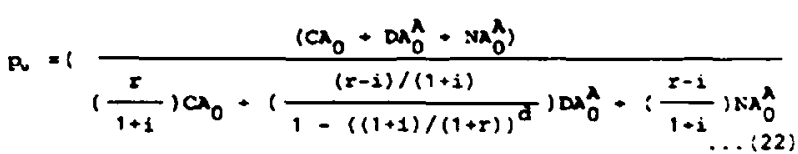


But:

$$
\begin{aligned}
& \frac{1+x}{1+1}=1+x_{n} \\
& \frac{x-1}{1+1}=x_{R}
\end{aligned}
$$

and therefore:

$$
\text { D. }=\left(\frac{\left(C \lambda_{0}+D A_{0}^{\lambda}+N A_{0}^{\lambda}\right)}{\left(\frac{r}{1+1}\right) C \lambda_{0}+\left(\frac{r_{R}}{1-\left(r_{R}\right)^{-d}}\right) D A_{0}^{A}+r_{R} \cdot N A_{0}^{\lambda}}\right.
$$

Uninflated payback cut-off for single asset projects

For the 100 percent current asset project:

$$
D_{0}^{\lambda}=N_{0}^{\lambda}=0
$$

Substituting into (19) and simplifying:

$$
\text { R. }=\left(\frac{1+1}{x}\right)
$$

For the 100 percent non-depreciable asset project.

$$
a_{0}=0 x_{0}^{\lambda}-0
$$

Substituting into (19) and simplifying:

$$
p_{*}=\frac{1}{x_{R}}
$$

For the 100 percent depreciable asset project:

$$
a_{0}=N_{0}^{A}=0
$$

Substituting into (19) and simplifying:

$$
\text { D. }=\left(\frac{1}{r_{R}}\right)-\left(\frac{1}{x_{R} \cdot\left(1+r_{R}\right)^{d}}\right)
$$

